\title{
Chapter 17 \\ Small Country, Complex Film Policy: \\ The Case of the Czech Film Funding \\ System
}

\author{
Petr Bilík
}

\subsection{Cultural Policy as a Dispute Between Two Concepts}

The cultural policy of the Czech Republic after 1989, when public administration once again became an ideological battlefield, is a locus of permanent conflict between two forces pulling in fundamentally different directions that cannot be firmly grasped in the common right-left perception of politics. The basic dispute is about the concept of the definition of public goods - the main question being, how much of a particular cultural good is needed in a society and what to do if the market fails to provide it?and the finding of a boundary that defines the range of influence of the state and the determination of the necessity of state intervention, whether in terms of support for or regulation of specific social spheres. While the care of thousands of listed buildings or the preservation of a vast network of public libraries, which are typical for the Czech Republic and unique in the European context, has been considered a priority by all post-socialist Czech governments and under all circumstances, many other cultural sectors (e.g., theater, dance and fine art) must repeatedly strive for attention (Nekolný 2006). One of the most interesting examples, interpreted quite differently from both poles of political philosophy, is cinema, which has an extraordinary degree of dependence on public funds and institutional background.

\footnotetext{
P. Bilík (凶)

Department of Theater and Film Studies, Faculty of Arts, Palacký University, Křížkovského 10, 77147 Olomouc, Czech Republic

e-mail: petr.bilik@upol.cz 


\subsection{Development of Film Policies and Funding Schemes After 1989}

In the Czech environment, the interpretation of how film should be supported by the state has been influenced by several factors with historical roots. The exclusive position of film was mainly due to the following factors:

- A strong cinematic tradition established at the end of the nineteenth century;

- A developed film production sector with an average of around 30 full-length feature films per year;

- A complex system of state-supported film economy under a centralized state management;

- An extraordinary network of cinema theaters offering around 2000 cinemas to the 10 million inhabitants of the Czech regions in 1989 (Central Film Rental Institute 1990: 3-10);

- Production facilities, especially at Barrandov Studios in Prague ${ }^{1}$;

- The iconic "Czech New Wave" movies of the 1960s and the tradition of animated cinema.

As a result of this heritage, film was considered by the majority of the stakeholders in the cultural domain (especially the audience, the politicians and, of course, the filmmakers) to be a privileged part of national culture, which must be developed as a part of the state's cultural policy. This interpretation was mainly held by filmmakers whose career culminated in the 1960s (e.g., Věra Chytilová, Jiří Krejčík).

Already at the very beginning of the transformation in 1989, the concept of film as a cultural and social necessity was rejected by a major part of the political spectrum adhering to neoliberal economic principles, according to which film should be approached as mainly a commercial good, whose production and distribution should follow the standard mechanisms of supply and demand. The view that the role of the state should be minimized was held, inter alia, by Pavel Tigrid, Minister of Culture and a famous writer.

Both these political streams were symbolically represented by prominent figures in the public sphere: While the neoliberal economic view was represented by the Minister of Finance, the Prime Minister and later President Václav Klaus, his opponent was, in particular, the Minister of Culture Pavel Dostál, who was inspired by the French model of supporting national culture and cinema and, more concretely, influenced by Jack Lang's socialist policy (Colin 2000). After the fall of the state film system, ${ }^{2}$ the wing headed by Pavel Dostál was looking for political partners to pass a law to secure future financial subsidies for filmmaking. Their arguments for state

\footnotetext{
${ }^{1}$ Established by businessman Miloš Havel as one of the largest and most modern studios in Europe in 1931.

${ }^{2}$ Until 1990, there was a complex of state film studios with their own financing system based on circulation of money.
} 
intervention in film remain valid to this day and address the lack of competitiveness of national film in Czech distribution and the global market. This is mainly due to the relatively high costs of film production and the small size of the national market and the language area.

The most important institution was and still is the Czech Film Fund (CFF), ${ }^{3}$ which distributes funds raised from the contribution from all cinema admissions and trading rights to Czech archive films that originated during the state monopoly. ${ }^{4}$ The producers calling for higher subsidies have pushed for additional funding to increase the budget of the CFF. The arguments are based on numerous international examples. In a situation where it seemed politically impossible to receive a share of the state budget (tax money), film professionals chose to lobby for new or higher levies from cinema admission proceeds, new forms of distribution and the commercial activities of television broadcasters. The ambition to establish a strong funding body with a mandate not only to subsidize film, but also to promote it internationally, was abandoned due to strong political resistance. For several years (especially 2004-2006), the most viable strategy was the effort to increase the income of the fund's budget. Especially the producers pointed out their vulnerability due to the high individual financial risks of investing in national cinema and the uncertainties of its international visibility.

Despite all the weaknesses of the system, Czech cinema has not disappeared. Over the last 20 years, private producers and Czech Television ${ }^{5}$ have maintained a high number of produced films per capita, as well as an extraordinary share in both attendance and sales. ${ }^{6}$ The Czech film industry has also made its mark by winning awards at international festivals as well, such as the Academy Award in 1996. ${ }^{7}$

\subsubsection{Accession to the EU}

With the accession of the Czech Republic to the European Union in 2004, an external authority came to defend the notion that domestic audiovisual production contributes to the creation of national identity. ${ }^{8}$ At the same time, Czech filmmakers began to point out the external benefits of film within the so-called cultural and creative

\footnotetext{
${ }^{3}$ Originally known as the fund for support and development of Czech cinema.

${ }^{4}$ The basic principles of the Fund were brought to the discussion just after the Velvet Revolution in 1989, and the institution was set up in 1992.

${ }^{5}$ Since the 1990s, the national public service broadcaster has been the most important co-producer of Czech cinema.

${ }^{6}$ After a decline in the 1990s, the number of Czech films has stabilized at above 30 feature-length films a year with the audience share exceeding $30 \%$ in some years.

${ }^{7}$ For the film Kolya (1996), directed by Jan Sverák.

${ }^{8} \mathrm{~A}$ summary is given, for example, in the Communication on Certain Legal Aspects Relating to Cinematographic Works and Other Audiovisual Works (European Commission 2002).
} 
industries, which not only supported their case for state support in parliament, but also helped to boost the self-awareness and self-confidence of the people involved in cultural affairs. To this day, EU policy is a crucial impulse for the national film industry.

\subsubsection{Finances and Funding}

Although the national legislative initiative to increase the budget for film funding was unsuccessful, after joining the EU a source of financial aid was established thanks to the process of digitization of television broadcasting. In 2010, an incentives program for foreign film production in the Czech Republic was launched, due to pressure from runaway productions and from a pure economic motive. ${ }^{9}$

Since approximately 2007, when the government increased the budget to support the film industry, ${ }^{10}$ the discourse has changed - the question whether or not to financially support the film industry is no longer discussed. The focus has switched to the particular design of the subsidy schemes. However, the increase of financial support, which almost tripled, raised a new set of questions. The most discussed issue was the relationship between quantity and quality. What are the objectives of financial support to the film industry and the definition of the film funding scheme in general? As in many other countries, stakeholders discussed whether film policy should pursue a popular culture approach, where film is accessible to a wide audience and funds are allocated to genre production, or if it should pursue a quality approach aiming to educate and uplift viewers and to win prestigious awards at international festivals.

Another branch of the discussion focused on maximizing the impact of film funding. First, a high percentage of scripts were developed and consequently produced, even though they did not meet the necessary quality standards to make a successful movie. This resulted in a large number of underfunded movies which met neither the goals of a commercial film industry nor those of a cultural funding rationale. As a solution, it was discussed to fund fewer projects with higher subsidies to increase the quality and hence the possibility of success.

\footnotetext{
${ }^{9}$ The economic analysis was carried out by the independent research group EEIP. The results of the report were the subject of many debates due to their bias toward seeing a positive economic impact of the film industry and the lack of considering negative (not only financial) aspects.

${ }^{10}$ Resulting from a promise made by Prime Minister Topolanek during the Karlovy Vary International Film Festival, when he stated: "We have promised that at least we would create an expert group immediately after our government was established and try to find the missing $€ 15.6$ million which the Czech film needs next year" (Míšková 2006).
} 


\subsection{New Law, New Conditions}

The sustainability of the new system and the higher level of support depended on the reconciliation of the various political forces and finding a more permanent social and political consensus. One of the essential questions regarding such support mechanisms was how the influence of individual participants in the film industry and also outside players (e.g., political parties and their interests, who could influence which projects were considered valuable) should be eliminated to build a systematic solution. To strengthen the public acceptance of the CFF, the representatives insisted on guaranteed transparency. The trustworthiness of the institution needed to be protected from direct political influence. ${ }^{11}$

The law to secure film funding in the Czech Republic passed in 2012 and took effect in 2013, exactly 20 years after the CFF was first established. It took long negotiations and a notification by the European Commission to put the legal changes into practice. The essential precondition for the EU was that the funding should not distort but rather foster competition within the audiovisual industry.

The most important body in the CFF is the board of film professionals and scholars, which not only grants the subsidies to particular film projects but also acts as a steering committee where long-term strategies are discussed and decided. The members are nominated by professional organizations from the audiovisual industry or the academic sphere, and with this recommendation, they are appointed by parliament. According to the legislation, the fund is not only the administrative body for cultural film funding, but also the host of economic film funding such as automatic support, and the administration of film incentives. Last but not least, the CFF is also the guarantor of co-productions and the methodological adviser in the field of general support and promotion of the film industry.

At the same time, the CFF draws its resources from a modified ticket levy (now $1 \%$ of box office, which led to a more than $20 \%$ increase in the income from levies), as well as from the growing market segment of commercial TV stations, which have won a prominent portion of the advertising market previously dominated by Czech Television.

The CFF regularly issues thematic calls targeting authors, producers, organizers and educational institutions. The received applications are then randomly assigned to expert reviewers for evaluation. In the next step, the evaluations and the applications are studied by all board members of the Czech Film Fund and discussed in an evaluating meeting. Successful projects must offer a good relationship between (1) creative and artistic potential, (2) appropriate economic investment and (3) an elaborate production strategy. All three criteria aim at minimizing the risk of investment for each and every project. Sufficient creative and artistic parameters are also

\footnotetext{
${ }^{11}$ The main shift was initiated thanks to the discussions on financing a film project called The Devil's Mistress (2016) directed by Filip Renč, which caused conflict over the principles of quality assessment and Fund procedures.
} 
a prerequisite for negotiated EU agreements and are therefore assessed as primary quality indicators in providing support. ${ }^{12}$

Aside from direct supply-side funding of film projects, the CFF supports the framework of the sector. The CFF sponsors a large number of activities such as workshops and consultations for producers, informational meetings during film festivals and promotional activities for new film production. Furthermore, the fund supports technical upgrades of theaters and screening equipment, film distribution and promotion, participation in festivals as well as professional training, publishing efforts and last but not least the preservation of film heritage.

\subsubsection{Support Typology}

The creative and production process itself is vertically divided into three phases:

- Script development;

- Complete development, where production necessities (casting, crew, location, visual concretization) are defined;

- Film production that results in a master copy.

In order to appropriately focus on different film genres and production types with different creative, technology and financial requirements, the current system is horizontally structured to support areas of animated, documentary and short films, which offer an interesting start in the professional sphere for filmmakers who still lack stature, or for student talents after graduating from film schools. Especially important is the call for feature-length debuts, which is supposed to help the growth of talents and their initiation into and connection with the professional community and to develop professional skills (e.g., their ability to create a project design, to describe a clear creative vision, to share teamwork and to establish a professional production strategy).

Support is also available to encourage a broader range of content in distribution and to familiarize the audience with art house films through promotion of selected foreign films in cinemas. At the same time, it is a diplomatic impulse for a similar, reciprocal approach to the Czech films abroad, although there are no binding contracts or arrangements for such a procedure.

\subsubsection{Minority Co-production}

A high value-added contribution is the fund's call to support minority co-productions leading the (mainly European) creative teams to cooperation, enhancing the exchange of know-how and encouraging networking on the basis of which domestic titles and

\footnotetext{
${ }^{12}$ The process of notification under this condition was successfully finalized in 2013.
} 
personalities can be integrated into national schemes in other countries. The transfer of symbolic capital based on festival awards and cross-border collaborations with internationally renowned filmmakers is also important. Over the years, the system has been improved and adapted several times and finally led to the funding scheme offered by the CFF since 2016 .

\subsubsection{The Current Funding Scheme}

In 2016, following a series of negotiations, producers, the CFF, the prime minister and the minister of culture reached an extraordinary agreement on the amendment to the audiovisual law that reinforced the position of film within the state's cultural policy and introduced an unprecedented second, symmetrical pillar to the existing parafiscal levies in the form of a mandatory contribution to film directly from the state budget.

\subsection{Mapping the Czech Film Industry}

In 2015, Szczepanik et al. published the first structural study of the Czech film industry which laid out a detailed map of the whole sector. The study included a number of suggestions for policymakers and funding bodies that were taken very seriously in the following year. These suggestions included a long-term monitoring system evaluating creative quality and a fixed funding scheme for script development and complete development. A very important outcome was the termination of further support for scripts that did not pass the prior assessment steps with excellent results. The changes strengthened the status of script editors and screenwriters and, within a few years, transformed the common practices of film companies, fostered trust in the relationship between the fund and the film industry, and not least helped to establish connections between the academic field and practical film production. Moreover, the extraordinary and overall respect that the study gained has become the basis for future mapping and development of new strategic planning tools. The year 2016 brought a new statute for the fund's Board and work on updating the long-term strategy which could already be based on findings that were intuitively suspected within the industry, but it was necessary to describe them statistically and further evaluate and verbalize them.

At the same time, the fund began to actively develop measures for professional education such as a script consulting incubator, ${ }^{13}$ an international program of workshops for screenwriters and script editors that offers multi-phase sharing experience and themes in a cyclic structure. In addition to passing on experience and know-how,

\footnotetext{
${ }^{13}$ The so-called Phoenix Project.
} 
one of the intended effects is for Czech filmmakers to think in a European dimension instead of targeting only a domestic market and audience.

\subsubsection{Attracting Runaway Productions}

In addition to selective support, the fund has administered a system of automatic incentives for audiovisual production since 2010, which has been implemented in the Czech Republic based on an economic rationale and to catch up with numerous neighboring countries that had introduced economic film funding earlier. The monetary incentives are perceived by politicians as a state investment, and the economic impact has been thoroughly debated and its evidence closely analyzed. ${ }^{14}$ The approximate return on investment from automatic support through incentives was assessed by the Ministry of Culture at about $118 \%$, which gradually grew to $150 \%$ according to CFF annual reports (2016).

After most runaway production left the Czech Republic for cheaper locations, a funding scheme was set up to attract foreign production once again. The main motivations were derived from experience abroad and from previous successful cooperation with blockbuster productions in the 1990s: The aim was to learn from the professional skills of foreign filmmakers and their staff, effectively use and modernize Czech infrastructure, gain financial benefits and to inspire the whole field of the national film industry (Aust 2009). Runaway productions receive a refund of up to $20 \%$ of eligible costs. The only condition is the fulfillment of a cultural test that guarantees cultural and value compliance with the Czech and European frameworks. Supported projects include domestic, European and American films, the latter of which are often the most expensive productions.

In 2016, when the system was simplified and optimized, the incentives were granted to a total of 50 projects in the amount of about $€ 32.5$ million, and in 2017 it was more than $€ 35$ million. ${ }^{15}$ However, after many meetings of the institutions involved and the Ministry of Finance, the $20 \%$ refund was increased to $25 \%$ of the eligible costs in the coming years (Hungary, the strongest competitor, offers $30 \%$ ) and the total budget will have to increase to almost $€ 47$ million.

\footnotetext{
${ }^{14}$ There were many experts and film industry members involved in the process of analysis (e.g., Stillking Production, scholars, the Ministry of Culture). The resulting material was published by the Ministry of Culture as "Concept of Support and Development of Czech Cinematography and the Czech Film Industry 2011-2016" (2010).

$15 € 33$ million and $€ 35.8$ million, according to the Czech Film Fund's Annual Reports from 2016 and 2017 , respectively.
} 
For improved complementarity of institutions supporting Czech film and better co-ordination of their activities, the Czech Film Commission ${ }^{16}$ and the Czech Film Centre $^{17}$ were incorporated into the CFF.

\subsection{Digitalization}

So far this chapter has described the development of Czech film policies after 1989 and where the industry stands today. However, during the period of consolidation of funding schemes and strategies, new challenges appeared that needed political, theoretical and practical attention. The Czech film industry in general (as well as the film industries in other countries) has had to come to terms with several historical periods and types of digitalization. The beginnings of cinema digitalization, which initially took place at single-screen cinema theaters, could be observed as early as 2008. This was mostly due to the efforts of local municipalities and particular cinema theaters to prepare for an inevitable global change. ${ }^{18}$ One year later, this trend was introduced into multiplex cinemas, while the Czech Film Fund prepared a long-term, nationwide grant scheme for the digitalization of an extensive network of cinema theaters, film productions had to deal with the change in technology independently and gradually one by one. The technology was first tested on smaller independent projects designed for online distribution, ${ }^{19}$ in order to be successfully introduced to mainstream projects later. ${ }^{20}$

The production sphere was skeptical about this phenomenon, undoubtedly due to a certain amount of distrust of the image quality as well as the artistic potential of digital technology. Meanwhile, the crucial driving point of its development within the distribution sphere was the high profits earned by foreign productions and the 3D blockbuster era.

At that time, when the local film culture was threatened by decline, single-screen cinema theaters, which were under substantial pressure from the global network of multiplex theaters, profited economically and strategically from the fact that these particular titles were immediately available after their premiere. Advancing digitalization of audiovisual content was accompanied by various challenges and risks, primarily in connection with the newly established illegitimate online distribution area.

\footnotetext{
${ }^{16}$ The Czech Film Commission was incorporated into the fund, among other things because its activities logically relate to the Fund's major duty to manage film incentives.

${ }^{17}$ The Czech Film Centre was originally established in 2002 as a private initiative in the period when Czech cinema lost its ability to effectively promote itself abroad.

${ }^{18}$ Kino Central Hradec Králové, cinema theater Central Hradec Kralove.

${ }^{19}$ Late Night Talks with Mother (2001).

${ }^{20}$ For example, the $4 \mathrm{~K}$ digitally compatible Catch the Billionaire (2009).
} 
The Czech territory was dominated by an online platform called ulozto.cz, which offered an immense quantity of both national and foreign titles free of charge and which became much more popular than the global torrent clients of previous years. Various organizations (e.g., the Czech Anti-Piracy Union, or OSA) as well as public institutions (e.g., the Ministry of Culture) started to perceive apparent violations of the Copyright Act and financial damage to the chain of production and distribution as an essential threat to the whole system, which led to the establishment of repressive measures as one of the priorities of future cultural policy. ${ }^{21}$ Only later was VOD distribution gradually legitimized by emerging legal servers, by the success of global VOD distribution networks and televisions, and also through the realization that viewer preference for consuming audiovisual content on TV screens and displays is for the most part irreversible.

Incentives were newly incorporated into the CFF strategic materials, and the dissemination of Czech movies through new distribution channels became a desirable aspect accompanying and widening the key goal of cinema theater distribution. The discussion, focused on the most suitable means of digital distribution of available film titles, has been essential for the CFF Board since 2016 and has remained crucial to the present day. ${ }^{22}$ It took thirty years to establish sustainable conditions for national cinema, and this effort is hopefully in its final stage. The reforms and initiatives have resulted in mechanisms which guarantee that films in cinema distribution are prioritized and that the state cultural policy (executed mainly through the CFF) respects this principle. This is the main reason why TV series designed for global channels and digital distribution, recently a very popular phenomenon, are still excluded from the established system of financial support for national film projects. Their producers are allowed to apply only for automatic support (incentives) along with foreign productions. In fact, the line between this type of art and the classic film format designed for cinemas is getting blurred. The stakeholders acknowledge this fact and are gradually preparing to adapt to it. Even the definition of "cinema distribution" and its rules are subject to reform. ${ }^{23}$

Unfortunately, the international availability of Czech national film production is not sufficient. Meaningful profit is often expected only within the Czech and Slovak territories, and sometimes the Polish area because of the insignificant language differences and low cultural barriers as well as familiar cast. The successful spread of Czech films within a network of foreign cinema theaters is so rare that it is not usually part of project budgets and most production companies connected with local distribution do not even target this goal. Even co-production titles are often released only on TV. Cross-border cinema theater release of new movies is almost out of the question. The recent $\mathrm{Czech}$ position in transactional video on demand (TVOD)

\footnotetext{
${ }^{21}$ Only some particular films had to be removed from uloz.to due to the legal regulations. Uloz.to is still active and has a strong influence on audience behavior and the audiovisual industry.

${ }^{22}$ The support of Filmtoro which offers all available film titles in Czech, with Czech dubbing or subtitles.

${ }^{23}$ While some TV or Internet series consider cinema premier, the minimal number of cinema screenings as a condition necessary to fulfill grant application eligibility criteria was lowered to 10 .
} 
distribution, where many Czech films are available, is more optimistic as opposed to subscription video on demand (SVOD) networks, where you can find only a few Czech film titles apart from European HBO GO. From a financial point of view, digital film distribution in other territories is still considered complementary. From this perspective, the concept of the European Digital Single Market (a EU proposal from 2015-2018) is rather a double-edged sword for the Czech film industry: The common markets could be opened up more effectively, but in the present situation the confidence in their own competitiveness is low and local distributors are not persuaded by claims about mutual cultural enrichment within the EU territory and the belief in the ability of European production to fight the American domination. The fear of losing the advantage of territoriality and possible disruption of the fragile support system is so overwhelming that it complicates other aspects of the issue as well as the challenges and possibilities of completely new solutions. ${ }^{24}$

\subsection{The Lack of Analysis and Future Hopes}

In spite of this, in 2016 the CFF decided to financially support a research project mapping the preparedness of the Czech territory to accept new conditions, and various other academic papers have also been taken into consideration since. Also, APA, the main Association of Czech Producers, is concentrating on future implementation and is trying to identify the most suitable way to incorporate Czech film productions into modern international digital networks and to widen their possible international impact. It seems that a thorough legal and economic analysis of the possible implementation of DSM is what the Czech territory and audiovisual sphere are still lacking in order to be able to articulate a clear approach and make a qualified decision on their standpoint with regard to any future discussions. Despite the complex and detailed ideas offered by European bodies, the Czech debate over the DSM issue is for most institutions and relevant stakeholders in its beginning stages.

Perhaps a few years of stabilization accompanied by another international success are the necessary conditions for this field of Czech national culture to attract global attention and to gain new self-confidence to be more active and open in this process. Right now, we can identify several impulses which could lead to success. ${ }^{25}$ However, the coming years could contain a certain risk factor: Europe and the DSM could develop at such a pace that Czech politicians would be seriously challenged to establish an appropriate course of cultural policy.

\footnotetext{
${ }^{24}$ In October 2019, Netflix introduced its Czech localization with 150 Czech film titles. Possible effects of further development are yet to be seen.

${ }^{25}$ Recently, The Painted Bird (2019) was accepted by festivals in Venice and Toronto. The short animated films Daughter (2019) and The Fruits of Clouds (2017) were also extraordinarily successful.
} 


\section{References}

Central Film Rental Institute. (1990). Závěrečný účet roku 1989. Zpravodaj ÚPF, No. 3.

Colin, J.-P. (2000). Le Mystère Lang. Chêne-Bourg: Georg.

Czech Film Fund. (2016). Výroční zpráva 2016. https://fondkinematografie.cz/assets/media/files/ H/VZ/vyrocni_zprava_2016.pdf. Accessed November 28, 2019.

European Commission. (2002). Communication from the commission to the council, the European parliament, the economic and social committee and the committee of the regions on certain legal aspects relating to cinematographic and other audiovisual works, $\operatorname{COM}(2001)$ 534 final. https://eur-lex.europa.eu/legal-content/EN/TXT/PDF/?uri=CELEX:52001DC0534\& from=EN. Accessed November 6, 2019.

Ministry of Culture of the Czech Republic. (2010). Concept of support and development of Czech cinematography and the Czech film industry 2011-2016. www.mkcr.cz/koncepce-podporya-rozvoje-ceske-kinematografie-a-filmoveho-prumyslu-2011-2016-536.html?searchString= koncepce\%20podpory. Accessed November 10, 2019.

Míšková, V. (2006). Filmaři jednali s politiky o kinematografii. Novinky, July 1. https://www. novinky.cz/odlozna/89591-filmari-jednali-s-politiky-o-kinematografii.html. Accessed November $10,2019$.

Nekolný, B. (2006). Divadelní systémy a kulturní politika. Praha: Divadelní ústav.

Szczepanik, P., Kotišová, J., Macek, J., Motal, J., \& Pjajčíková, E. (2015). A study of feature film development in the Czech Republic. Prague: Czech Film Fund.

Petr Bilík is Assistant Professor at the Department of Film and Theater Studies, Palacký University Olomouc. He specializes in Czech and Central European film culture and the management of cultural and creative industries. From 2015 to 2018, he was a member of the Board of the State Cinematography Fund and helmed two projects based on mapping regional and national creative industries. He is experienced in the field of production and the festival distribution of audiovisual content, having served as a commissioning editor at Czech TV, the head of Academia Film Olomouc and founder and head of the PAF film festival.

Open Access This chapter is licensed under the terms of the Creative Commons Attribution 4.0 International License (http://creativecommons.org/licenses/by/4.0/), which permits use, sharing, adaptation, distribution and reproduction in any medium or format, as long as you give appropriate credit to the original author(s) and the source, provide a link to the Creative Commons license and indicate if changes were made.

The images or other third party material in this chapter are included in the chapter's Creative Commons license, unless indicated otherwise in a credit line to the material. If material is not included in the chapter's Creative Commons license and your intended use is not permitted by statutory regulation or exceeds the permitted use, you will need to obtain permission directly from the copyright holder.

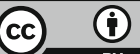

